\title{
Excretion and persistence of bovine coronavirus in neonatal calves
}

\author{
Brief Report \\ Sanjay Kapil ${ }^{1}$, Ava M. Trent ${ }^{2}$, and Sagar M. Goyal ${ }^{1}$ \\ Departments of ${ }^{1}$ Veterinary Diagnostic Investigation and of ${ }^{2}$ Large Animal \\ Clinical Sciences, College of Veterinary Medicine, University of Minnesota, St. Paul, \\ Minnesota, U.S.A.
}

Accepted July 9, 1990

\begin{abstract}
Summary. Following oral inoculation, the excretion of a virulent or an attenuated strain of bovine coronavirus in calf feces and their persistence in spiral colon, ileum, and jejunum were studied using hemagglutination and direct fluorescent antibody tests, respectively. The virus was excreted in feces for only 3 days at high titers and then intermittently at low titers. However, viral antigen was detected in crypt or Peyer's patches for at least 3 weeks after infection in 1 of 3 calves given virulent virus and 1 of 2 calves given attenuated virus.
\end{abstract}

Bovine coronavirus (BCV) is an important cause of diarrhea in calves of 3-21 days of age [8]. This virus is known to cause a more severe disease and higher mortalities than those caused by the bovine rotavirus because it multiplies in both the small intestine and the large intestine whereas the rotavirus infects only the small intestine [12]. The main route of infection is the fecal-oral and the pregnant cows are believed to be important sources of virus for newborn calves. Cows have been reported to be chronic excretors of BCV; the shedding being exacerbated in late stages of gestation, probably because of hormonal changes and their effects on the immune system $[1,2]$.

An attenuated virus vaccine is available to control $\mathrm{BCV}$ diarrhea, but has not been found to be efficacious in protecting from infection under experimental conditions [3] or in the field in colostrum-fed calves [11]. To determine the reasons for vaccine failure, information is needed on the replication sites, titers, and persistence of BCV following infection. Information is also needed on the mode of presentation of the antigen to the immune sytem as well as the extent of mucosal immune responses engendered by $\mathrm{BCV}$. 
Saif et al. [9] studied the replication sites of a pneumoenteric strain (strain DB2) of BCV in calves of 3-50 days of age and found that the virus multiplied in the gut and the upper respiratory tract. Research is underway in our laboratory to evaluate the intestinal immunity in $\mathrm{BCV}$-infected calves and to understand the reasons for vaccine failure. As a part of this research, we studied the excretion and persistence of BCV in experimentally infected calves to determine their ability to clear viral infection.

Colostrum-deprived, unvaccinated, male Holstein calves were obtained immediately after birth and were transported to an isolation facility. The calves were housed in individual rooms and were fed a milk replacer (Land-O-Lakes, Fort Dodge, Iowa) twice daily. Each calf received daily doses of $2 \mathrm{ml}$ of a $48 \%$ suspension of Tribrissen (sulfadiazine and trimethoprim, Coopers Animal Health, Kansas City, Kansas) orally and $5 \mathrm{ml} / 100 \mathrm{lb}$ of Naxcel (ceftiofur sodium, Upjohn Company, Kalamazoo, Michigan) intramuscularly throughout the experiment. At 5 days of age, the calves were inoculated orally with different doses of virulent (pneumoenteric isolate) or attenuated strain (Mebus strain) of BCV (Table 1). During the course of the study, a control uninfected calf became naturally infected with $\mathrm{BCV}$ at 4 days of age and was included in the study. The attenuated BCV (Mebus strain) was obtained from the National Veterinary Services Laboratory, Ames, Iowa where it had undergone 38 passages in PK 15 (pig kidney) cells. An additional 3 passages in human lung carcinoma (A 549) cells were given in our laboratory. The virulent isolate of BCV was obtained from a fecal sample submitted to the Minnesota Veterinary Diagnostic

Table 1. Groups of calves for virus inoculation ${ }^{\mathrm{a}}$

\begin{tabular}{llll}
\hline Calf group & Virus inoculation & Calf no. & Clinical signs \\
\hline I & Attenuated virus & 1 & None \\
& & 9 & Excess mucus \\
II & Virulent isolate & 2 & Diarrhea \\
& & 6 & Pneumonia, diarrhea \\
& & 7 & Pneumonia, diarrheic feces \\
III & Natural infection & 3 & with blood and mucus \\
IV & Uninfected control & 4 & Diarrhea \\
& & 5 & None \\
& & 8 & None \\
\hline
\end{tabular}

${ }^{a} I$ Inoculated with tissue culture adapted, attenuated virus; (32 HA units per $25 \mu 1$ ). The virus titer in cell cultures was $1.35 \times 10^{6} \mathrm{TCID}_{50}$ per $\mathrm{ml}$. Calf \#1 was given $4 \mathrm{ml}$ of this preparation whereas calf \# 9 received $20 \mathrm{ml}$; II inoculated with virulent, pneumoenteric field isolate of bovine coronavirus ( $256 \mathrm{HA}$ units per $25 \mu 1$ ). Calves \#2, 6, and 7 received $7 \mathrm{ml}, 20 \mathrm{ml}$, and $15 \mathrm{ml}$ of virus, respectively; III calf \# 3 was an uninfected control but became naturally infected with a bovine coronavirus during the study at 4 days of age; $I V$ uninfected, control calves 
Laboratory, St. Paul, MN for diagnostic purposes from a week old calf with diarrhea.

A $20 \%$ suspension of the sample was prepared in Hank's balanced salt solution (HBSS), clarified by centrifugation at $2500 \times \mathbf{g}$ for $20 \mathrm{~min}$ and passed through a $0.45 \mu \mathrm{m}$ filter. No bacteria were isolated when the filterate was inoculated on blood agar plates. On examination by negative contrast electron microscopy (NCEM), the sample was found to contain coronavirus only. No bovine viral diarrhea (BVD) virus was detected on inoculation of bovine turbinate cells followed by staining with FITC-labelled BVD conjugate.

Fecal samples were collected daily from all calves including control calves directly from the rectum. A $20 \%$ (w/v) suspension of feces was made in HBSS. The suspensions were centrifuged at $2500 \times \mathrm{g}$ for $20 \mathrm{~min}$ at $4^{\circ} \mathrm{C}$ and the supernatants were stored at $-70^{\circ} \mathrm{C}$ until tested.

The virus titer in the feces was determined by hemagglutination test (HA) using rat erythrocytes. Twofold dilutions of fecal samples were made in HA buffer (phosphate buffer saline with $0.1 \%$ bovine serum albumin, $\mathrm{pH} 7.2$ ). To this was added, $25 \mu 1$ each of $1 \%$ rat erythrocytes and HA buffer and the test was incubated at $10^{\circ} \mathrm{C}$ for $90 \mathrm{~min}$. The HA titer was considered to be the reciprocal of the highest dilution showing complete matting of erythrocytes at the bottom of the wells. The HA activity of virus was confirmed by hemagglutination-inhibition. The control calves (except calf \#3) did not show any hemagglutination activity.

Right flank laparotomies were performed to collect full thickness gut wall biopsies from spiral colon, ileum, and jejunum for the detection of BCV antigen by the direct fluorescent antibody (DFA) test. Since BCV infects both the small and the large intestines a method was needed for sampling from both regions of the intestines of these calves at various time intervals. The Thiry Vella loops can not be made with spiral colon while small intestine is not accessible by retrograde endoscopy. Also, it was necessary to collect full thickness biopsies to study the involvement of Peyer's patches in virus infection. Laparotomies at various intervals after infection allowed the collection of full thickness samples from all sites. Attempt was made to cover every weekly interval after infection among a group. The details of the laparotomy procedure are given elsewhere [6]. Briefly, the calves were sedated with xylazine hydrochloride (Rompun) at the rate of $0.02-0.05 \mathrm{mg} / \mathrm{kg}$ intravenously and $0.04-0.1 \mathrm{mg} / \mathrm{kg}$ intramuscularly and restrained in left lateral recumbency. The right flank was clipped and paralumber fossa prepared for surgery by scrubbing alternately with Betadyne and $70 \%$ alcohol. A regional block was done with $20-30 \mathrm{ml} 2 \%$ Lidocaine in inverted $\mathrm{L}$ pattern. A $15-20 \mathrm{~cm}$ vertical incision was made in mid-flank. The muscle layers were separated in grid pattern and peritoneum sharply incised. Intestinal biopsies, $4-5 \times 2-3 \mathrm{~mm}$ in size, were placed in normal saline and were transported on wet ice to the laboratory. The incision was closed in routine manner. 
The DFA was done on frozen sections of gut biopsies from all calves from spiral colon, ileum, and jejunum. The sections $(6 \mu \mathrm{m})$ were placed on slides, air dried, washed with PBS ( $\mathrm{pH} 7.2$ ) for $5 \mathrm{~min}$, fixed in acetone for $10 \mathrm{~min}$, covered with FITC-labelled anti-BCV antibody (gnotobiotic calf origin) and incubated at room temperature for an hour. After counterstaining with Evan's blue, the sections were examined with fluorescent microscope. Samples showing finely granular cytoplasmic, apple green fluorescence were considered positive.

The clinical signs of inoculated calves are shown in Table 1. Calf \#1, after inoculation with the attenuated virus, did not develop any clinical signs, while calf \#9, inoculated with 5 times the dose of the same virus developed loose feces, excess mucus and an increase in fecal $\mathrm{pH}$. The peak HA titers of the virus were 16-32 in feces and they persisted for 1-3 days (Fig. 1). After this time, the HA activity could be detected only intermittently and at low titers. Calves inoculated with the virulent virus, developed interstitial pneumonia, upper respiratory tract infection and diarrhea [5] and excreted BCV at HA titers of 512-8192 for 2-3 days followed by a drop in titers to 2-8 (Fig. 2). The naturally infected calf (\#3) had a peak HA titer of 2048 which, after 3 days, decreased to 2 . Failure to achieve high titers with attenuated virus may be the reason for the failure of attenuated $\mathrm{BCV}$ vaccines $[4,7]$.

Full thickness gut wall biopsies were collected and examined by DFA to avoid missing BCV in any part of the gut wall. All three regions (spiral colon, ileum, and jejunum) of the gut tested were positive for BCV at various times, e.g., at the peak of infection in calf \#7 and a week later in calf \#6. In most of the calves, the BCV antigen was localized in one or more of these 3 regions of the gut (Table 2). Saif et al. [9] have also reported the differences in the per-

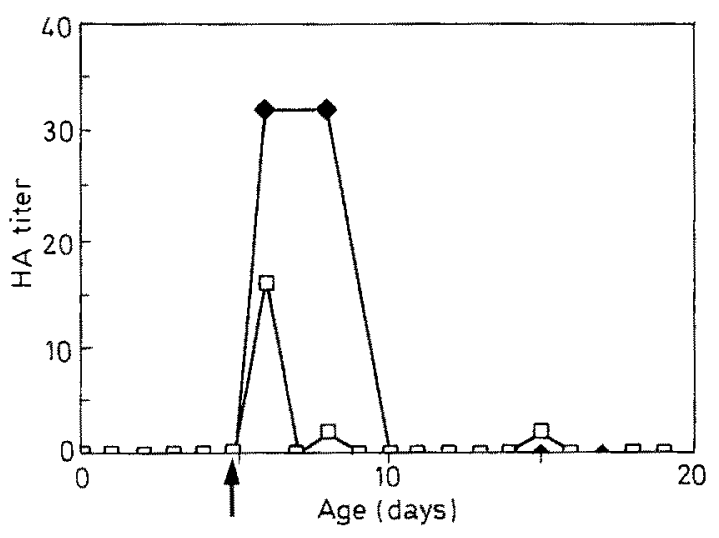

Fig. 1

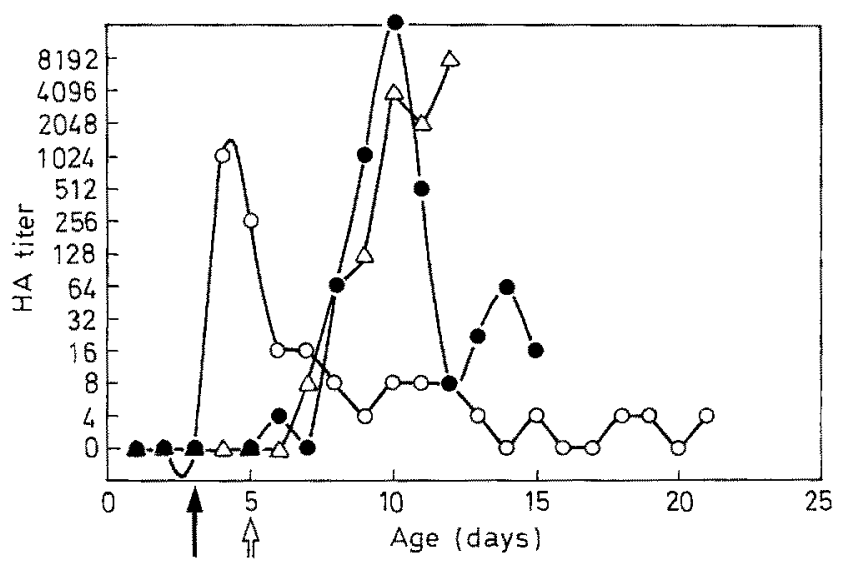

Fig. 2

Fig. 1. Hemagglutination activity in calf feces $(\square \# 1, \square \# 9)$ following oral infection (arrow) with attenuated bovine coronavirus

Fig. 2. Hemagglutination activity in calf feces following oral infection with virulent, pneumoenteric strain of bovine coronavirus. Calf \#2 (O) was inoculated at 3 days of age (solid arrow) while calves \#6 $(\bullet)$ and $7(\triangle)$ were inoculated at 5 days of age (open arrow) 
Table 2. Detection of bovine coronavirus in different regions of the gut of infected calves ${ }^{a}$

\begin{tabular}{|c|c|c|c|c|c|c|}
\hline \multirow[t]{3}{*}{ Treatment } & \multirow[t]{3}{*}{ Calf no. } & \multicolumn{5}{|c|}{ Virus detection in calf organs $s^{b, c}$} \\
\hline & & \multicolumn{5}{|c|}{ days postinoculation (age, days) } \\
\hline & & $2(7)$ & $7(12)$ & $14(19)$ & $21(26)$ & $28(33)$ \\
\hline \multirow{2}{*}{ Attenuated virus } & 1 & $\mathrm{SC}$ & $\mathrm{SC}$ & - & - & - \\
\hline & 9 & ND & $\mathrm{SC}, \mathrm{I}$ & ND & $\mathrm{I}, \mathrm{J}$ & ND \\
\hline \multirow[t]{3}{*}{ Virulent virus } & 2 & $\mathbf{J}$ & - & - & $\mathrm{SC}, \mathrm{I}$ & ND \\
\hline & 6 & ND & $\mathrm{SC}$ & SC, I, J & ND & ND \\
\hline & 7 & ND & $\mathrm{SC}, \mathrm{I}, \mathbf{J}$ & ND & ND & $\mathrm{ND}$ \\
\hline \multicolumn{2}{|l|}{ Natural infection 3} & $\mathbf{J}$ & $\mathrm{SC}, \mathrm{I}$ & ND & $\mathbf{J}$ & ND \\
\hline \multirow[t]{3}{*}{ Uninfected } & 4 & ND & - & - & ND & ND \\
\hline & 5 & ND & - & ND & - & ND \\
\hline & 8 & ND & - & - & - & ND \\
\hline
\end{tabular}

${ }^{a}$ Virus inoculation was done at 5 days of age

${ }^{b}$ Virus was detected by direct fluorescent antibody test in $S C$ spiral colon, $I$ ileum, $J$ jejunum

${ }^{c}$ Preinfection surgery was done at day 2 in all calves and all organs were virus negative - Not detected

$N D$ Not done, duodenal sections were not examined

centage of positive fluorescing cells in the duodenum, jejunum, ileum, and spiral colon, in calves of 3-50 days of age inoculated with a pneumoenteric strain of bovine coronavirus. For diagnostic purposes the intestinal content and a piece of spiral colon are usually submitted for NCEM and DFA, respectively. Since the virus may not be present in spiral colon at all times, it may be easy to miss. This may explain the failure of correlation of EM results and DFA as reported before [10]. In the acute stage, both virulent and attenuated strains of BCV infected the superficial enterocytes in the intestine. However, the attenuated strain was seen to persist in Peyer's patches (calf \#9) while the virulent strain persisted in the crypts (calf \#2) for up to 3 weeks.

Although $\mathrm{BCV}$ is sensitive to environmental conditions, coronaviral scours may occur in a herd year after year, especially in winter. Under current management conditions, calves are usually separated from dams immediately after birth and reared separately from adult cows. Therefore, the virus must persist somewhere in the calf pens or environment. Although cows are considered to be the source of BCV for calves, the excretion of low titers of BCV in calves indicates that these calves may be another possible source of the virus for other calves. The intermittent demonstration of the viral antigen in the gut of the calves seems to substantiate this hypothesis.

In conclusion, the excretion of $\mathrm{BCV}$ in neonatal calves seems to have a peak phase followed by a phase of low level excretion of the virus. The latter is 
characterized by low or nondetectable levels of BCV excretion in calf feces as detected by the hemagglutination test. Clinically the phase of low level of excretion coincided with malabsorption and severe loss of body weight in calf \#2.

\section{Acknowledgements}

Published as contribution No. 18201 of the series of the Minnesota Agricultural Experiment Station. Partial funding for this project was provided by the Minnesota Agricultural Experiment Station. We thank Ms. Pin King for technical assistance.

\section{References}

1. Collins JK, Riegel CA, Olson JD, Fountain A (1987) Shedding of enteric coronavirus in adult cattle. Am J Vet Res 48: 361-365

2. Crouch CF, Bielefeldt OH, Watts TC, Babiuk LA (1985) Chronic shedding of bovine enteric coronavirus antigen-antibody complexes by clinically normal cows. J Gen Virol 66: $1489-1500$

3. DeLeeuw PW, Tiessink JWA (1985) Laboratory experiments on oral vaccination of calves against rotavirus or coronavirus induced diarrhea. Zentralbl Veterinarmed [B] 32: $55-64$

4. Kapil S, Trent AM, Goyal SM (1989) Intestinal immune responses of newborn calves to bovine enteric coronavirus infection. In: 70th Annual Meeting Conf Research Workers Animal Disease. Chicago, Illinois, abstract no 73: 15

5. Kapil S, Pomeroy K, Goyal SM, Trent AM (1990) Coronavirus infection in calves: respiratory tract involvement. In: 31st Annual Meeting North Central Vet Lab Diagnosticians. Fargo, North Dakota, abstract no 2: 2

6. Kapil S, Trent AM, Goyal SM, Srikumaran S (1990) Antibody responses in spiral colon, ileum, and jejunum of bovine coronavirus-infected neonatal calves. Reg Immunol (submitted)

7. Kapil S, Trent AM, Goyal SM (1990) Immune response in spiral colon, ileum, and jejunum of coronavirus-infected colostrum-deprived calves. In: 90th Annual Meeting Am Soc Microbiol Anaheim, California, abstract no E-51: 128

8. Saif LJ, Heckert RA (1990) Enteric coronaviruses. In: Saif LJ, Theil KW (eds) Viral diarrheas of man and animals. CRC Press, Boca Raton, FL, pp 185-252

9. Saif LJ, Redman DR, Moorhead PD, Theil KW (1986) Experimentally induced coronavirus infections in calves: Viral replication in the respiratory and intestinal tracts. Am J Vet Res 47: 1426-1432

10. Naeem K, Goyal SM (1988) Comparison of virus isolation, immunofluorescence, and electron microscopy for the diagnosis of animal viruses. Microbiologica 11: 355-362

11. Thurber ET, Bass EP, Beckenhauer WH (1977) Field trial evaluation of a reo-coronavirus calf diarrhea vaccine. Can J Comp Med 41: 131-136

12. Torres-Medina A, Schlafer DH, Mebus CA (1985) Rotaviral and coronaviral diarrhea. Vet Clin North Am [Food Anim Pract] 1: 471-493

Authors' address: S. M. Goyal, Department of Veterinary Diagnostic Investigation, University of Minnesota, St. Paul, MN 55108, U.S.A.

Received April 27, 1990 